\title{
BEDLOAD TRANSPORT AND MORPHOLOGICAL EFFECTS OF HIGH-MAGNITUDE FLOODS IN SMALL HEADWATER STREAMS - MORAVSKOSLEZSKÉ BESKYDY MTS. (CZECH REPUBLIC)
}

\author{
TOMÁŠ GALIA, JAN HRADECKÝ
}

Department of Physical geography and geoecology, Faculty of Nature, University of Ostrava, Chittussiho 10, 71000 Ostrava, Czech Republic; Mailto: tom.galia@ seznam.cz, jan.hradecky@ osu.cz

Bedload transport observed during a flood in May 2010 gave rise to several forms of accumulations in small headwater basins located in the Western Flysch Carpathian Mountains, Czech Republic. We have investigated critical conditions of incipient motion of the largest boulders deposited during a c. $Q_{100}$ flood event (flood competence method). We have tested several formulas designed for high gradient streams in two small basins in the conditions of local mid-mountain relief. The results show that a flood of such a magnitude is able to transport almost all surface bed material and that bedload transport in steep headwater streams $\left(\mathrm{A} \leq 1 \mathrm{~km}^{2}\right)$ is probably less selective as for the grain size than that in lower gradient gravel-bed streams. The authors discuss the importance of local basin predispostion factors in order to determine critical conditions for the onset of bedload transport.

KEY WORDS: Incipient Motion, Bedload Transport, Headwater Stream, Moravskoslezské Beskydy Mts.

Tomáš Galia, Jan Hradecký: DNOVÝ TRANSPORT A MORFOLOGICKÁ ODEZVA MIMOŘÁDNÝCH POVODNÍ NA MALÝCH PRAMENNÝCH TOCÍCH - MORAVSKOSLEZSKÉ BESKYDY (ČESKÁ REPUBLIKA). J. Hydrol. Hydromech., 59, 2011, 4; 35 lit., 6 obr., 6 tab.

Dnový transport sedimentů zapříčinil během květnových povodní v roce 2010 vznik různých typů akumulací v malých pramenných tocích nacházejících se ve flyšových pohořích Západních Karpat. Studie se zaměřuje na určení kritických podmínek nutných pro uvedení největších klastů do pohybu, jež byly následně uloženy do akumulací během této cca $Q_{100}$ povodně (metoda účinnosti povodně). V rámci výzkumu byly ověřeny některé rovnice vytvořené pro vysokogradientové toky na dvou malých povodích v podmínkách reliéfu hornatin. Výsledky ukazují, že povodeň takové intenzity je schopna transportovat téměř celou povrchovou vrstvu sedimentů a dnový transport je na malých povodích pravděpodobně méně velikostně selektivní než v tocích s nižším gradientem dna. Důraz byl kladen také na lokální predizpoziční faktory ovlivňující kritické podmínky pro uvedení určité velikostní frakce sedimentů do pohybu.

KLÍČOVÁ SLOVA: počátek pohybu, dnový transport, pramenný tok, Moravskoslezské Beskydy.

\section{Introduction}

In recent years $(1997,2009,2010)$, the area of the Moravskoslezské Beskydy Mts has been affected by extraordinary flood events. As such natural hazards represent risk to human life as well as cause considerable material damage, there is a need to focus on source zones, especially small steep headwater basins located in a mountainous terrain. The investigation of processes and relations in channel-reach and/or channel-hillslope systems during flood events allows us to improve watersheed management and consequently to reduce risks and property damages.
High gradient streams are defined as steep and confined channel segments found in mountainous terrains containing gravel, cobble and boulder substrates (Wohl and Merritt, 2008) and characterized by potential occurrence of exposed bedrock outcrops (Montgomery and Buffington, 1997; Nickolotsky and Pavlowsky, 2008). Bed gradient is higher than $0.002 \mathrm{~m} / \mathrm{m}$ (Wohl and Merritt, 2008); however, other authors usually define high gradient streams as having much steeper gradients of minimally $0.01 \mathrm{~m} / \mathrm{m}$ (e.g. Thompson et al., 2006). Therefore, based on bed gradient criteria of Wohl and Merritt (2008), gravel-bed rivers located in piedmont areas can be considered as high gradient 
channels. In other cases within our paper, we speak about headwater streams, which are defined as streams of the first or second order (Strahler, 1955) or of the first order only (Halwas and Church, 2002). Benda (2005), focusing on the resolution of topographic maps in order to clearly distinguish first-order streams and second-order streams, points out the uncertainity as for the exact definition of the first-order streams results from the concept of smooth transition of slopes into colluvial channels.

Headwater stream beds containing coarse sediment are relatively resistant to erosive processes (Vianello, D'Agostino, 2007). The rate of sediment transport in headwater streams depends on sediment supply rather than the capacity of flow ( $Y u$ et al., 2010). Both fluvial and colluvial processes participate in the formation of steep headwater channels (Montgomery and Buffington, 1997). The components of hydraulic roughness in steep torrents are represented by grain resistance and form resistance. Therefore, the total flow resistance cannot be described sufficiently only by a characteristic percentile of the grain size distribution (Aberle and Smart, 2003). At the same time, bedload transport may be affected by the presence of bed forms that are composed of interlocked cobbles and boulders (Rickenmann et al., 2006; Church and Zimmerman, 2007).

The rate of bedload transport in gravel- and boulder-bed streams can be expressed in two different ways:

i. Firstly, it is the calculation of bedload discharge, which represents the amount of material transported in a channel cross-section under specific flow conditions. Many formulas for the calculation of bedload discharge during peak flows were published in the last decades (e.g. Bagnold, 1980; Parker, 1990; Barry et al., 2004) especially for gravel-bed streams, however not for steep headwater channels and small basin areas $(<10$ $\mathrm{km}^{2}$ ) characterized by the combination of colluvial and fluvial transport processes and the presence of vertically-oscillating bedforms like steps and pools. Despite big effort and variety of data, there are still significant differences in the results of models of bedload transport in gravel-bed rivers (Barry et al., 2008). Recently, a sediment routing model for steep Alpine torrents has been presented by Rickenmann et al. (2006). In addition, Molnar et al. (2010) are using a method of exact measurement of a stream bed longitudinal profile before and after a flood event to estimate volumes of deposited or eroded material. ii) Secondly, it is possible to use some critical conditions corresponding to the incipient motion of a particle of a certain diameter. Several methods and approaches have been investigated to describe the incipient motion of grains in headwater streams. Mao et al. (2008) distinguish flow competition, flood competition and marked particle displacement. The first two approaches identify the magnitude of flow or flood which is capable of transporting or depositing boulders of certain sizes. In order to provide correct measurement within these approaches, it is advisable to use bedload traps or geophone sensors installed in gauging stations (Rickenmann, 1997; Demir and Walsh, 2005; Mao et al., 2008). Gob et al. (2003) have applied a method of lichenometric dating to reconstruct flow magnitudes which were able to transport large boulders in Corsican streams. Finally, the method of marked particle displacement is based on regular observations of the motion of marked and mapped particles located in a stream bed or channel bars (Mao et al., 2008).

The flood event in May 2010 left a number of fluvial accumulations of various extent within active channels of Beskydian headwater streams. Most of the accumulations formed as a result of dam-like effect of trees that had fallen into the channel due to bank failures activated by the flood. In some cases accumulations formed behind woody debris jams. Other predisposition factors included limited space between an active channel and adjoining side-slopes, the presence of large immovable boulders or a local decrease in the channel gradient.

This paper intends to describe critical conditions for the formation of small accumulations in local headwater channels. More concretely, we make effort to calculate values of critical shear stress, velocity, unit stream power and unit discharge, which had an effect on transport and consequent deposition of the largest boulders into channel forms during a c. $Q_{100}$ flood. We also deal with a hypothesis of bedload transport character of steep channels and compare it with lower gradient streams. The most traditional term used to describe the force the incipient motion of a particle needs is critical shear stress $\tau_{c i}\left[\mathrm{~N} \mathrm{~m}^{-2}\right]$ acting on a particle $D_{i}[\mathrm{~m}]$, which can be expressed as

$\tau_{c i}=\left(\rho_{f^{-}} \rho_{p}\right) \cdot \tau^{*}{ }_{c i} \cdot \mathrm{g} . D_{i}$

where $\rho_{f}$ is fluid density, $\rho_{p}$ - density of a particle, $\tau^{*}{ }_{c i}$ - dimensionless shear stress or the so-called Shields parameter, $\mathrm{g}-$ the acceleration caused by 
gravity and $D_{i}$ is the length of the b-axe of a particle in meters. For $D_{i}$, the following values can be introduced: $D_{84}$ (Zimmerman and Church, 2001), $D_{50}$ (Buffington and Montgomery, 1997) or the b-axe of a certain particle of any size (Lenzi et al., 2006; Mao et al., 2008). However, as we discuss further in the text, the calculation of $\tau^{*}{ }_{c i}$ involves a certain degree of uncertainity. On the other hand, alternative boundary conditions of the incipient particle motion such as critical velocity, discharge and stream power have been explored by a number of authors (e.g. Costa, 1983; Lenzi et al., 2006; Mao et al., 2008; Williams, 1983).

\section{Study area}

The mountainous part of north-eastern Moravia belongs to regions most exposed to precipitation in the Czech Republic (Mt Lysá hora 1440 mm/annual precipitation). In May 2010, streams in the southeastern part of the Odra River basin reached flood discharges of different interval recurrence (e.g. the Jičínka Stream in Nový Jičín $Q_{20}$; the Lubina Stream in Petřvald na Moravě and the Lučina Stream in Domaslavice $Q_{50}$; the Ostravice River in Frýdek-Místek up to $Q_{100}$ - influence of the Šance Reservoir; the Morávka River in Vyšní Lhoty > $Q_{100}$ - influence of the Morávka Reservoir) (Povodí Odry 2010). Cumulative discharge in the Lower Malá Ráztoka Stream $\left(2.01 \mathrm{~km}^{2} ; Q_{a}=0.061 \mathrm{~m}^{3} \mathrm{~s}^{-1}\right)$, situated in the northern part of the Radhošt'ská hornatina Mts, reached $3.96 \mathrm{~m}^{3} \mathrm{~s}^{-1}$ on 18 May 2010, which corresponds to 100-200 year recurrence interval discharge derived from 1953-2007 time series. To make comparison, $Q_{1}$ discharge is about $0.3-0.4 \mathrm{~m}^{3} \mathrm{~s}^{-1}$ and $Q_{5}$ is equivalent to $1.25 \mathrm{~m}^{3} \mathrm{~s}^{-1}$.

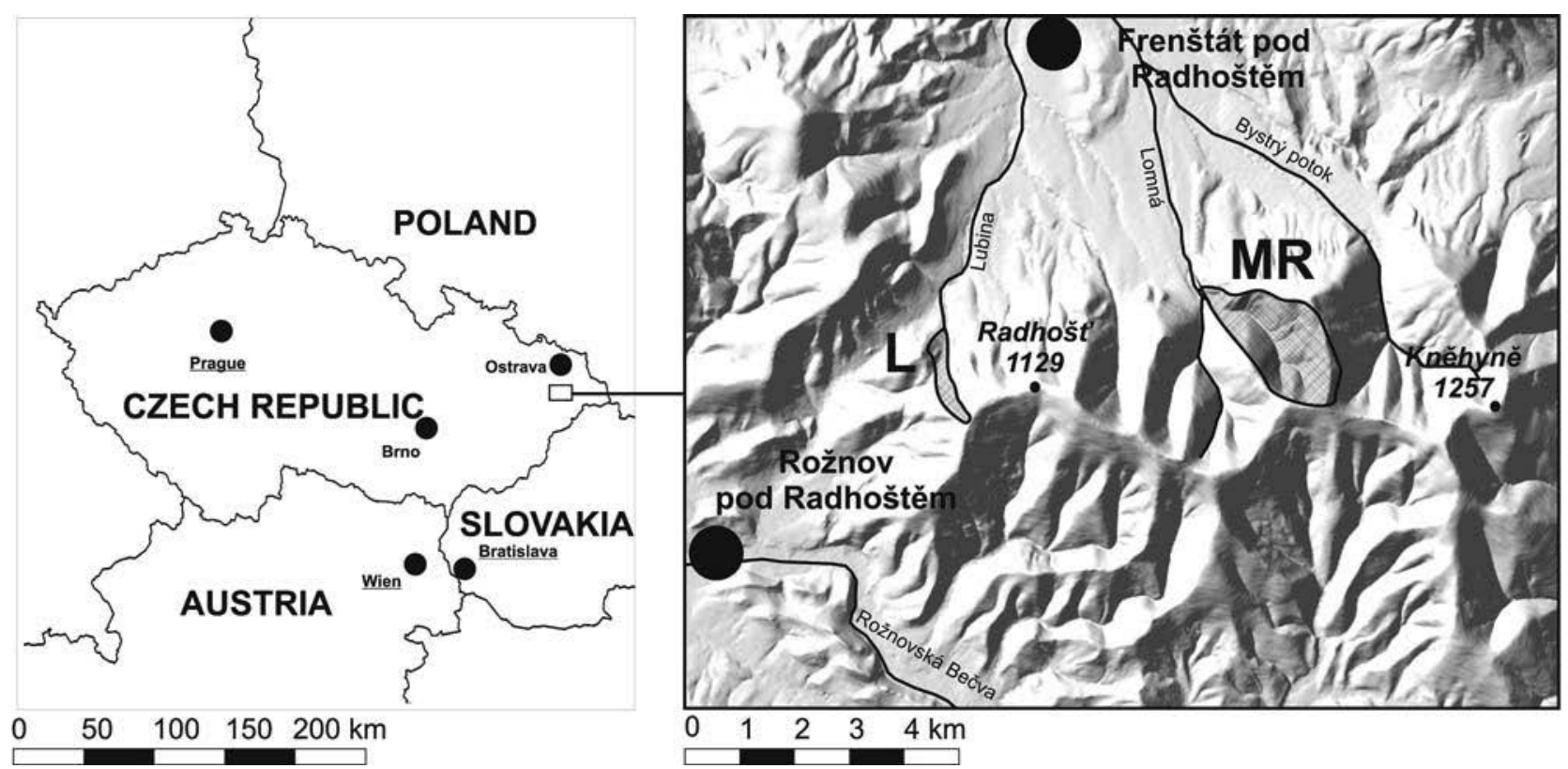

Fig. 1. Location of the studied basins (MR - the Malá Ráztoka Stream and L - the uppermost part of the Lubina Stream).

Our study area occupies two small basins located in the northern part of the Radhošt'ská hornatina Mts $\left(49^{\circ} 29^{\prime} \mathrm{N}, 18^{\circ} 14^{\prime} \mathrm{E}\right)$ - the Malá Ráztoka Stream and the uppermost reach of the Lubina Stream. Average year temperature in the Malá Ráztoka basin is $6.9{ }^{\circ} \mathrm{C}$ and the mean annual precipitation is $1244 \mathrm{~mm}$, namely $651 \mathrm{~mm}$ in the warm period and $553 \mathrm{~mm}$ in the cold period of a year (Chlebek and Jařabáč, 1995). The altitude varies from 560-1080 m in the Malá Ráztoka basin and 530-980 $\mathrm{m}$ in the upper Lubina basin respectively. Mean slope gradients of subbasins upstream the studied reaches varies between $17.2 \%$ and $19.7 \%$ in the Lubina basin. In two reaches of the Malá Ráztoka basin we obtained the values of $25.3 \%$ and $25.8 \%$ by extracting gradients from 1: 10000 DEM. The Malá Ráztoka stream bed has predominantly sandstone character with a minimum amount of claystone clasts (less than 5\% of the total amount). This is due to the local occurence of mainly sandstone flysch middle-part of the Godula Formation (Cretaceous period) where claystone layers are rather poorly represented and, moreover, they are far less geomorphologically resistant than 
massive sandstone benches. By contrast, claystone particles play a more important role in the bed structure of the upper reach of the Lubina Stream (about $30-50 \%$ of the total amount). Channel reaches in the upper Lubina Stream are based on predominantly claystone formations such as the Lhoty Formation and the Veřovice Formation. These reaches were also enriched by Godula Formation sandstone clasts, the transport of which was enabled by slope processes from the culmination parts of the Radhošt'ská hornatina Mts. Generally, both the basins are influenced by deep-seated slope deformations in the culmination parts of ridges (Pánek et al., 2007), vertical erosion, occurence of bank failures and minor slope movement in downstream parts in response to geological predispositions.

\section{Methods}

A majority of the studied reaches are cascade or step-pool channels according to a classification established by Montgomery, Buffington (1997). The LU7 reach was identified as a plane bed channel, while the MR2 reach as a combination of a cascade channel and a bedrock channel (Tab. 1). Seven reaches manifesting the presence of small postflood accumulations (L1-L7 reaches) were investigated in the upper Lubina basin and two reaches (MR1, MR2) were studied in the Malá Ráztoka basin, while each of the reaches contained 1-3 locations of post-flood deposits. The maximal observed length of such forms developed between active channels and adjacent slopes was 14 meters (L7 reach) and the width was up to 3 metres (L7 and MR1 reaches). Top points of the accumulation in
L6 reach were one metre high above the $Q_{a}$ water surface, which may have been caused by the stream bed erosion during the flood or temporary damming of the channel. Maximal heights of the other accumulations did not exceed 0.6 metres above the local water surface.

The measurement on the Malá Ráztoka Stream made use of the gauging station situated nearby the confluence with the Lomná Stream. For the MR1 and MR2 reaches located in the upper part of the Malá Ráztoka basin as well as for the Lubina reaches (LU1-LU7), the discharge records were obtained using a specific simple discharge method, generally used by the Czech Hydromeorological Institute in case of small headwater basins.

The paper focuses on the composition of relatively small accumulations located in upper parts of the basins. After the May 2010 flood event, geometrical parameters of each accumulation were measured as well as the $a, b$, and $c$ axes of 15-20 largest particles deposited on the surface of accumulations. We suppose that the boulders travelled through the channel-reach immediately above the accumulations during the flood event. Therefore, measuring 100 particles in each profile, we were able to obtain cross-section profiles, bed gradients and particle-size characteristics of these channelreaches using classical Wolman (1954) method. Geometrical characteristics (i.e. cross-section profiles) were only taken in positions where we had supposed low dynamics of lateral or vertical erosion during the flood. The profiles contained specific signs of water stage height such as the height of scoured leaves, exposed roots or a significant presence of scour lines.

T a b l e 1. Characteristics of the studied reaches.

\begin{tabular}{lcccccccccc}
\hline Reach & $L[\mathrm{~km}]$ & $A\left[\mathrm{~km}^{2}\right]$ & $S[\mathrm{~m} / \mathrm{m}]$ & Channel morf. type & Clay. $[\%]$ & $D_{50}[\mathrm{~m}]$ & $D_{90}[\mathrm{~m}]$ & $W_{f}[\mathrm{~m}]$ & $d_{f}[\mathrm{~m}]$ & $Q_{f d e r}\left[\mathrm{~m}^{3} \cdot \mathrm{s}^{-1}\right]$ \\
\hline L1 & 0.5 & 0.20 & 0.09 & Step-pool & 50 & 0.040 & 0.140 & 2.8 & 0.40 & 0.40 \\
L2 & 0.5 & 0.20 & 0.11 & Step-pool & 39 & 0.045 & 0.140 & 2.8 & 0.30 & 0.40 \\
L3 & 0.6 & 0.25 & 0.12 & Step-pool & 39 & 0.045 & 0.120 & 2.5 & 0.30 & 0.50 \\
L4 & 0.6 & 0.25 & 0.11 & Step-pool & 39 & 0.045 & 0.120 & 2.8 & 0.40 & 0.50 \\
L5 & 0.7 & 0.28 & 0.10 & Cascade & 39 & 0.050 & 0.155 & 3.3 & 0.45 & 0.56 \\
L6 & 0.7 & 0.28 & 0.12 & Cascade & 29 & 0.045 & 0.160 & 3.0 & 0.45 & 0.56 \\
L7 & 0.8 & 0.35 & 0.06 & Plane bed & 34 & 0.045 & 0.155 & 3.0 & 0.35 & 0.70 \\
MR1 & 0.7 & 0.85 & 0.14 & Cascade & 5 & 0.050 & 0.165 & 7.0 & 0.40 & 1.70 \\
MR2 & 1.2 & 1.41 & 0.11 & Bedrock-Cascade & $<1$ & 0.045 & 0.145 & 3.4 & 0.35 & 2.81 \\
\hline
\end{tabular}

$L$ is a distance downstream, A - the area of subbasin upstream of a reach, $S$ - a channel gradient, Clay. - a ratio of claystones to sandstones of all surface bed material, $D_{50}$ and $D_{90}$ - particle-size indexes of surface bed material, $w_{f}-$ the flood channel width, $d_{f}-$ an estimated flood channel depth, $Q_{f d e r}-$ derived culminative discharge during the 5/2010 flood. 


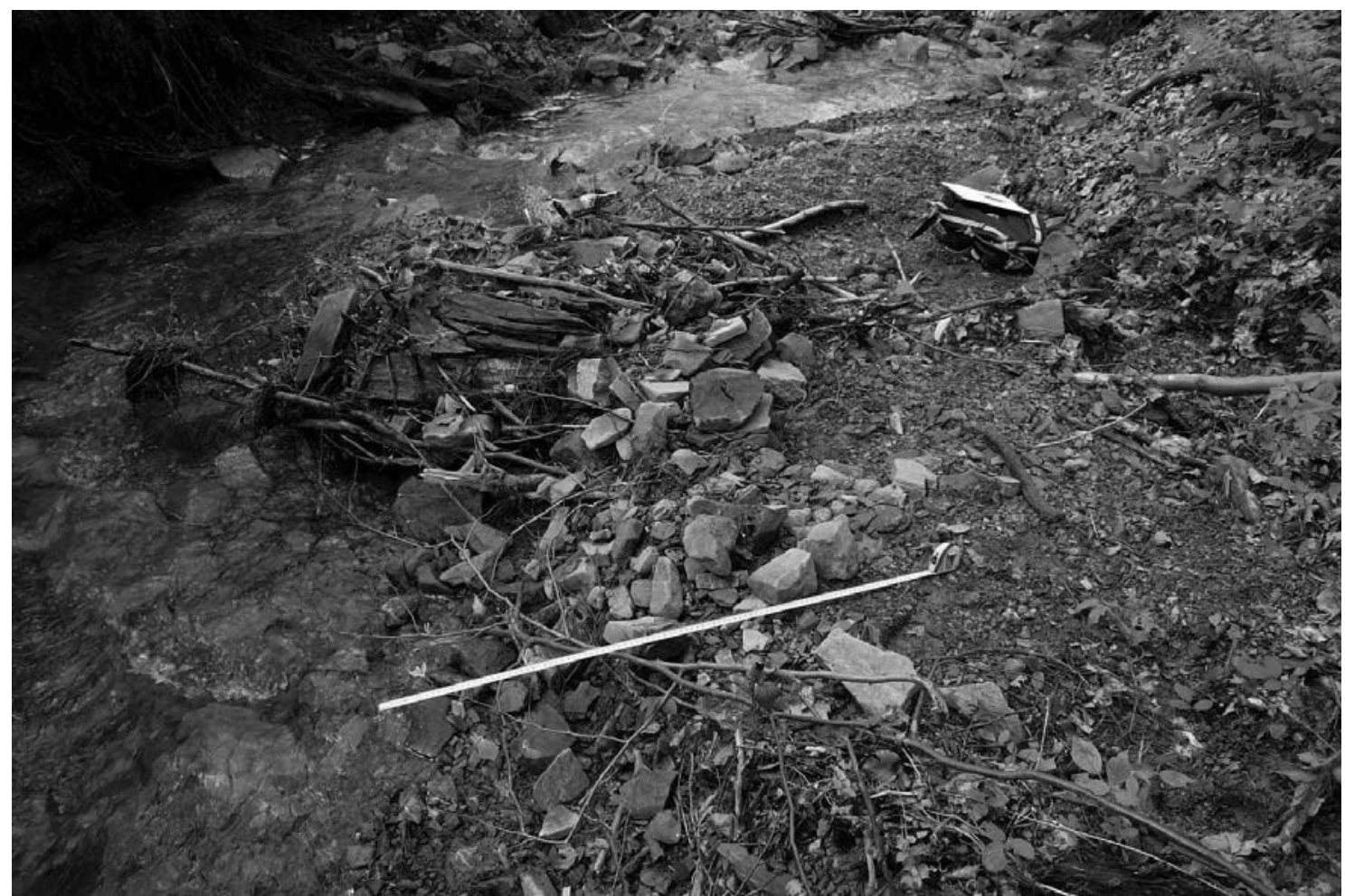

Fig. 2. Flood accumulation in L1 reach.

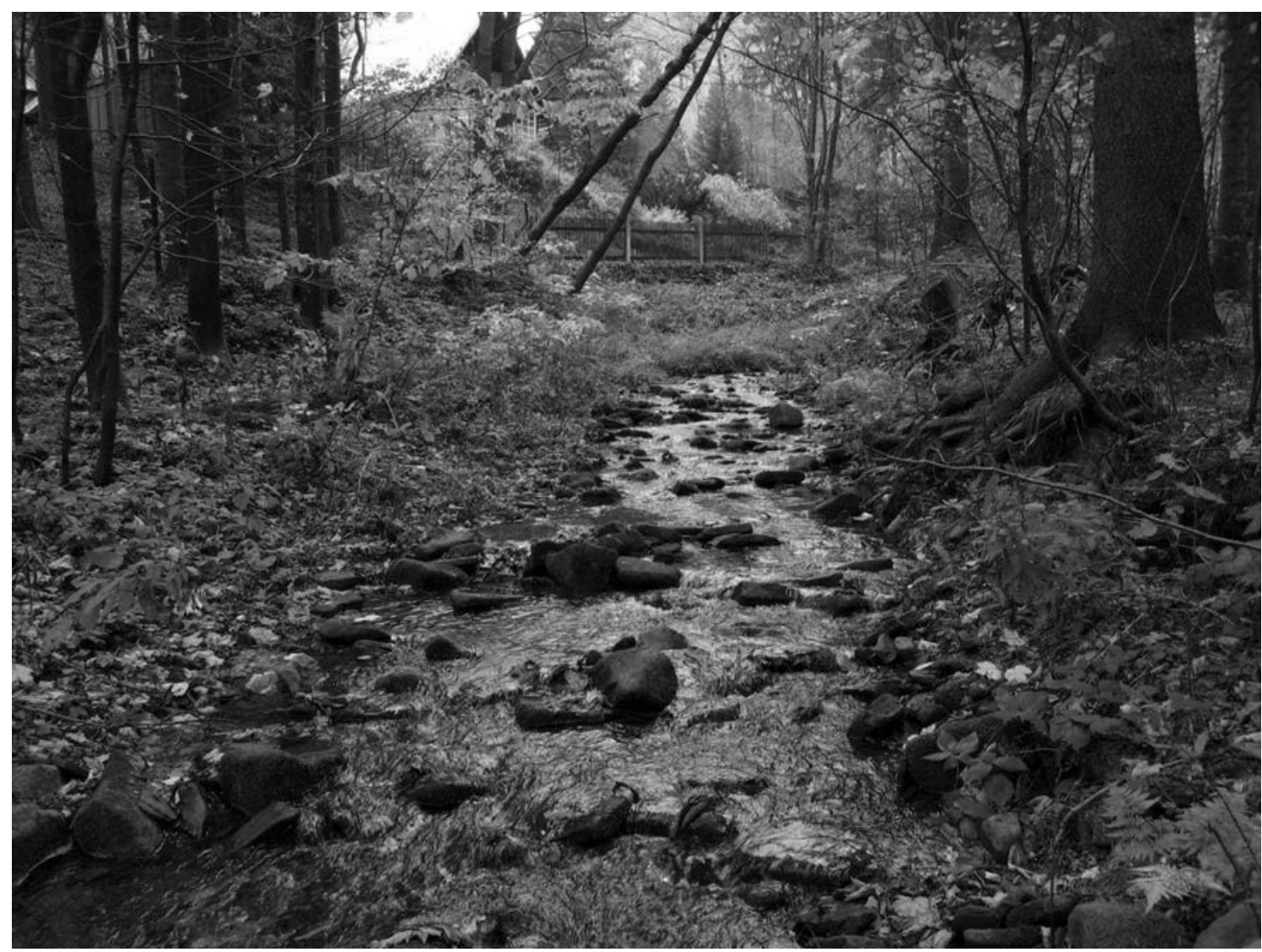

Fig. 3. Low flow conditions in the Malá Ráztoka Stream $0.2 \mathrm{~km}$ downstream of the gauging station. 


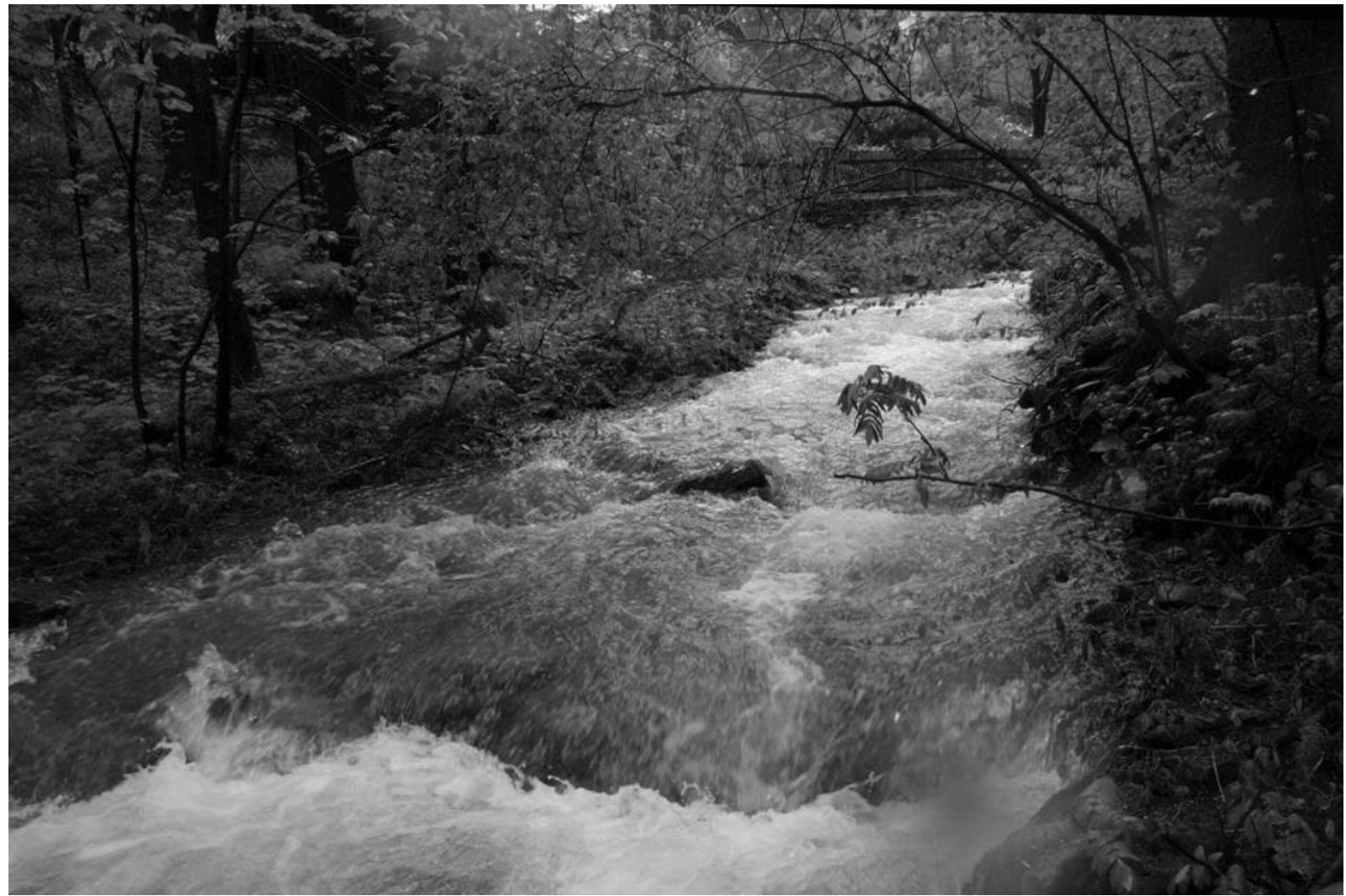

Fig. 4. Bankfull stage observed in the same reach as in Fig. 3 (discharge about $1 \mathrm{~m}^{3} \mathrm{~s}^{-1}$ ).

As indicated above, there is certain inaccuracy related to the estimation of dimensionless shear stress $\tau^{*}{ }_{\mathrm{ci}}$ in Eq. (1). Shields (1936) recommends the value of 0.045 for heterogeneous bed mixture. Zimmerman and Church (2001) use and compare the values of $0.03,0.045$ and 0.06 to calculate potential bedload transport in step-pool reaches. Lenzi et al. (2006) conducted his research in Alpine steep boulder-bed streams and introduced empirical equations based on $D_{i} / D_{50}$ and $D_{i} / D_{90}$ relationships to describe dimensionless shear stress acting on grain $D_{i}$. The equations are as follows:

$\tau^{*}{ }_{c i}=0.143\left(D_{i} / D_{50}\right)^{-0.737}$,

$\tau^{*}{ }_{c i}=0.054\left(D_{i} / D_{90}\right)^{-0.737}$.

Lenzi et al. (2006) also states it is better to use higher bed-sediment percentiles $\left(D_{90}\right)$ in order to describe conditions in coarse grained mountain streams. Lamb et al. (2008) presumes strong dependence of dimensionless shear stress on the slope of the stream bed in steep channels. His flume experiments led to the equation:

$\tau^{*}{ }_{c i}=0.15 \cdot S^{0,25}$, where $S$ is the channel gradient $\left[\mathrm{m} \mathrm{m}^{-1}\right]$. Buffington and Montgomery (1997) revised previous studies of gravel-bed rivers and point to a wide range of dimensionless shear stress values for $D_{50}$ (i.e. 0.03$-0.086)$.

There are some other empirical relationships that can describe the incipient motion of grains in mountain streams such as critical velocity (Costa, 1983; Rickenmann et al., 2006), critical discharge (Lenzi et al., 2006; Mao et al., 2008) or critical stream power (Petit et al., 2005; Mao et al., 2008). If geometric parameters of a channel under certain discharge are known, stream power per unit $\omega\left(\mathrm{W} \mathrm{m}^{-2}\right)$ can be calculated in the following way:

$\omega=\left(\rho_{f} Q . S . g\right) / w$,

where $w$ is the channel width in meters. Several authors have published equations to calculate values of critical stream power per unit necessary to transport a particle of a certain grain diameter. On the basis of a large amount of data Williams (1983) derived the following empirical equation of potential incipient motion of bed material for cobble- and boulder-bed streams:

$\omega_{c i}=0.079 D_{i}{ }^{1,3}$ 
and it is valid for $10<D_{i}<1500$, where $D_{i}$ is in [mm].

On the grounds of recent research, Mao et al. (2008) established a different equation:

$\omega_{c i}=31.502 D_{i}^{0.488}$,

which was derived analyzing data obtained by the methods of flow competence, flood competence and particle displacement in boulder-bed step-pool streams in Alpine and Andean environments (Rio Cordon basin, Tres Arryoyos basin) and it is reliable for a wide range of particle sizes (c. 2-1000 $\left.\mathrm{mm}, \mathrm{R}^{2}=0.853\right) . \mathrm{D}_{\mathrm{i}}$ is the length of b-axis of a particle in $\mathrm{mm}$. Using flood competence data only, the relationship takes a slightly different form:

$\omega_{c i}=47.227 D_{i}^{0.475}\left(R^{2}=0.754\right)$.

Using unit discharge $q=Q / w\left[\mathrm{~m}^{2} \mathrm{~s}^{-1}\right]$ and critical flow velocity in a channel to characterize fluvial bedload transport in headwater stream is applicable as well. Lenzi et al. (2006) derived a relationship between critical unit discharge $q_{c i}$ and $D_{i}$ (in meters):

$q_{c i}=1.176 D_{i}^{0.641}$.

To calculate critical velocity it is possible to employ a transformed Karman-Prandtl-Keulegan (KPK) equation, which was adjusted by Zimmermann and Church (2001) to describe flow resistance in steep step-pool streams. It takes the form

$v_{c i}=\left(\tau_{c i} /\left(\rho \cdot k^{2} /(\ln 14.4)^{2}\right)^{1 / 2}\right.$,

where $v_{c i}$ is critical flow velocity $\left[\mathrm{m} \mathrm{s}^{-1}\right]$ and $k-\mathrm{a}$ von Karman constant $\sim 0.4$. Eq (9) is dependent on correct calculation of $\tau_{\mathrm{ci}}$ by above mentioned methods.

If geometrical parameters of a channel in flood conditions are known, it is possible to calculate Manning $n$ roughness coefficient of wellestablished Manning equation. This was first introduced as an alternative to the Chezy equation in 1889 to describe the mean velocity of uniform flow:

$v=1 / n \cdot R^{2 / 3} \cdot S^{1 / 2}$,

where $v$ is the mean velocity of stream flow $\left[\mathrm{m} \mathrm{s}^{-1}\right]$, $R$ - a hydraulic radius of a channel cross-section [m]. As it was mentioned above, the total hydraulic roughness is divided into grain and form components. Hence, in contrast to low-gradient rivers, we must recognize Eq. (11), especially its Manning $n$ coefficient, as an approximation of overall conditions in a specific channel-reach of a stream during a flood event because of high variety of total roughness among individual steps, pools and runs.

\section{Results}

\subsection{Dimensionless and critical shear stress}

At first, we calculated a range of values of dimensionless shear stress for each reach (using Eq. (3) and Eq. (4)) and consequently critical shear stress necessary for the transport of the largest particles to the accumulations and their deposition (using Eq. (1)). Due to non-uniform particle size distribution of bed sediments, the values of dimensionless shear stress are slightly different. As the MR1 reach in the Malá Ráztoka basin contains the coarsest bed material, the values of dimensionless shear stress for a certain size of grains are slightly higher than the values corresponding to grains of the same size in the Lubina reaches. Results of the particle-size analysis of the MR2 reach bed are influenced by its bedrock-cascade morphology and a large amount of fine particles deposited in pools between bedrock outcrops in the channel. However, the largest particles that have been deposited on the surface of the MR1 and MR2 accumulations are less coarse than the largest particles found in identical accumulations in the upper Lubina basin. There are three hypotheses related to this finding:

a) It seems that except some sporadic cases steplike accumulations composed of large stones $(b$ axis $>0.4 \mathrm{~m}$ ) in the upper Malá Ráztoka basin were left untransformed during the flood. Large boulders thus represent very stable forms. Therefore, it is colluvial processes such as debris flows or shallow landslides that play an important role in putting the boulders in motion in small headwater channels.

b) Large stones are transported along the thalweg only and not deposited in accumulations on the sides of the stream channel. However, some larger stones deposited near banks of the channel can initiate the formation of accumulations since they function as roughness elements dissipating kinetical energy of the stream ('keystones').

c) Our research focuses on the study of particles that were deposited during the May 2010 flood only. However, some larger stones may have been buried completely in less coarse sediment of the accumulations throughout the whole time of the accumulation formation. In such a case, it cannot be clearly determined whether these particles were transported to the accumulations by 
the May 2010 flood or whether they had been located in situ before and in this way functioned as initiators of the formation of accumulations.

The values of dimensionless shear stress obtained by Eq. (3) vary between 0.25 and 0.4 for the largest transported boulders and cobbles $(b$ axis $>$ $0.2 \mathrm{~m})$. However, in case of small particles of c. 5 $\mathrm{cm}$ in diameter these values increase to $0.10-0.13$. This is connected to the so-called 'shadow effect' of larger particles in relation to smaller ones, protrusion effect of larger particles and close packing of fine bed material. The values obtained by Eq. (4), dependent on the channel slope and valid for all bed material, are significantly higher and vary from 0.074 to 0.092 . They nearly correspond to $D_{50}-D_{90}$ bed particle size values obtained by Eq. (3) (Tab. 2 ). The values of dimensionless shear stress and critical shear stress acting on certain boulders during the flood are shown in Tab. 3. They were calculated using Eq. (1) with the values of dimensionless shear stress obtained by Eq. (3). The values of critical shear stress, as well as other critical parameters (velocity, discharge, stream power), are directly related to the largest stones found in the accumulations; therefore the magnitudes of these parameters are likely to be slightly higher during the culmination of the flood.

$\mathrm{B}(1-5)$ are lengths of $b$-axis of the largest particles deposited in the accumulations with $b \geq 0.2 \mathrm{~m}$, $\mathrm{B}(1-5) \tau^{*}{ }_{\mathrm{ci}}$ are values of dimensionless shear stress acting on boulders $\mathrm{B}(1-5)$ and $\mathrm{B}(1-5) \tau_{\mathrm{ci}}$ are values of critical shear stress acting on boulders $\mathrm{B}(1-5)$ during 5/2010 flood.

$\mathrm{T}$ a b 1 e 2. Values of dimensionless shear stress acting on bed particles obtained by Eq. (3) $\left(D_{i}=0.01,0.05,0.1,0.2,0.3,0.4\right.$ and $0.5)$ and Eq. (4) for all surface bed material $\left(D_{i}=\right.$ all $)$.

\begin{tabular}{lccrccccc}
\hline Reach & $D_{i}=0.01 \mathrm{~m}$ & $D_{i}=0.05 \mathrm{~m}$ & $D_{i}=0.1 \mathrm{~m}$ & $D_{i}=0.2 \mathrm{~m}$ & $D_{i}=0.3 \mathrm{~m}$ & $D_{i}=0.4 \mathrm{~m}$ & $D_{i}=0.5 \mathrm{~m}$ & $D_{i}=$ all \\
\hline L1 & 0.381 & 0.116 & 0.070 & 0.042 & 0.031 & 0.025 & 0.021 & 0.082 \\
L2 & 0.380 & 0.117 & 0.070 & 0.042 & 0.031 & 0.025 & 0.021 & 0.086 \\
L3 & 0.340 & 0.104 & 0.062 & 0.037 & 0.028 & 0.022 & 0.019 & 0.088 \\
L4 & 0.341 & 0.104 & 0.062 & 0.037 & 0.028 & 0.022 & 0.019 & 0.088 \\
L5 & 0.410 & 0.125 & 0.075 & 0.045 & 0.033 & 0.027 & 0.023 & 0.084 \\
L6 & 0.419 & 0.128 & 0.077 & 0.046 & 0.034 & 0.028 & 0.023 & 0.088 \\
L7 & 0.408 & 0.125 & 0.075 & 0.045 & 0.033 & 0.027 & 0.023 & 0.074 \\
MR1 & 0.427 & 0.130 & 0.078 & 0.047 & 0.035 & 0.028 & 0.024 & 0.092 \\
MR2 & 0.387 & 0.118 & 0.071 & 0.042 & 0.032 & 0.025 & 0.022 & 0.086 \\
\hline
\end{tabular}

$\mathrm{T} \mathrm{a} \mathrm{b} 1 \mathrm{e}$ 3. Values of dimensionless and critical shear stress acting on the largest boulders stored in the accumulations obtained by Eq. (1) and Eq. (3)

\begin{tabular}{|c|c|c|c|c|c|c|c|c|c|c|c|c|c|c|c|}
\hline Reach & $\begin{array}{c}B 1 \\
{[\mathrm{~m}]}\end{array}$ & $\begin{array}{c}B 2 \\
{[\mathrm{~m}]}\end{array}$ & $\begin{array}{c}B 3 \\
{[\mathrm{~m}]}\end{array}$ & $\begin{array}{c}B 4 \\
{[\mathrm{~m}]} \\
\end{array}$ & $\begin{array}{l}B 5 \\
{[\mathrm{~m}]}\end{array}$ & $B 1 T_{c i} *$ & $B 2 T_{c i}{ }^{*}$ & $B 3 T_{c i}{ }^{*}$ & $B 4 T_{c i}{ }^{*}$ & $B 5 T_{c i} *$ & $\begin{array}{r}B 1 T_{c i} \\
{\left[\mathrm{~N} \mathrm{~m}^{-2}\right]} \\
\end{array}$ & $\begin{array}{r}B 2 T_{c i} \\
{\left[\mathrm{~N} \mathrm{~m}^{-2}\right]} \\
\end{array}$ & $\begin{array}{r}B 3 T_{c i} \\
{\left[\mathrm{~N} \mathrm{~m}^{-2}\right]} \\
\end{array}$ & $\begin{array}{r}B 4 T_{c i} \\
{\left[\mathrm{~N} \mathrm{~m}^{-2}\right]} \\
\end{array}$ & $\begin{array}{c}B 5 T_{c i} \\
{\left[\mathrm{~N} \mathrm{~m}^{-2}\right]}\end{array}$ \\
\hline L1 & 0.35 & 0.21 & - & - & - & 0.028 & 0.040 & - & - & - & 147.4 & 128.9 & - & - & - \\
\hline L2 & 0.30 & 0.28 & 0.24 & 0.23 & - & 0.031 & 0.033 & 0.037 & 0.038 & - & 141.9 & 139.4 & 133.9 & 132.4 & - \\
\hline L3 & 0.33 & 0.32 & 0.29 & 0.28 & 0.27 & 0.026 & 0.026 & 0.028 & 0.029 & 0.030 & 129.7 & 128.7 & 125.4 & 124.3 & 123.1 \\
\hline L4 & 0.29 & 0.27 & 0.24 & 0.23 & 0.22 & 0.028 & 0.030 & 0.033 & 0.034 & 0.035 & 125.0 & 122.7 & 119.0 & 117.6 & 116.3 \\
\hline L5 & 0.40 & 0.38 & 0.33 & 0.29 & 0.28 & 0.027 & 0.028 & 0.031 & 0.034 & 0.035 & 164.5 & 162.3 & 156.4 & 151.1 & 149.7 \\
\hline L6 & 0.34 & 0.32 & 0.31 & 0.30 & 0.28 & 0.031 & 0.033 & 0.033 & 0.034 & 0.036 & 160.9 & 158.4 & 157.1 & 155.7 & 152.9 \\
\hline L7 & 0.32 & 0.31 & 0.27 & 0.26 & 0.25 & 0.032 & 0.032 & 0.036 & 0.037 & 0.038 & 154.4 & 153.1 & 147.6 & 146.2 & 144.7 \\
\hline MR1 & 0.35 & 0.33 & 0.32 & 0.28 & 0.27 & 0.031 & 0.032 & 0.033 & 0.037 & 0.038 & 165.5 & 162.9 & 161.6 & 156.0 & 154.6 \\
\hline MR2 & 0.32 & 0.31 & 0.30 & 0.27 & 0.26 & 0.030 & 0.031 & 0.032 & 0.034 & 0.035 & 146.2 & 145.0 & 143.8 & 139.9 & 138.5 \\
\hline
\end{tabular}

$\mathrm{B}(1-5)$ are lengths of $\mathrm{b}$-axis of the largest particles deposited in the accumulations with $\mathrm{b} \geq 0.2 \mathrm{~m}, \mathrm{~B}(1-5) \tau^{*}{ }_{c i}-$ values of dimensionless shear stress acting on boulders $\mathrm{B}(1-5)$ and $\mathrm{B}(1-5) \tau_{c i}$-values of critical shear stress acting on boulders $\mathrm{B}(1-5)$ during $5 / 2010$ flood.

\subsection{Critical velocity, stream power and discharge}

We calculated critical velocity of the incipient motion by the KPK Eq. (9). The values obtained for larger particles $\left(0.2 \mathrm{~m}>D_{i}>0.4 \mathrm{~m}\right)$ range between
1.3 and $1.7 \mathrm{~m} \mathrm{~s}^{-1}$ depending on critical shear stress (Tab. 4). Such critical velocity values are in contrast to values calculated using the equation presented by Rickenmann (2006):

$$
v=\left(1.93 \mathrm{~g}^{0.5} \cdot S^{1.5} \cdot h^{0.5}\right) / D_{90} \text {. }
$$


If we apply local geometrical parameters of flood channel cross-sections ( $h$ is flow depth in metres) and $D_{90}$ of bed sediment to Eq (11), we obtain quite unrealistically high values of flow velocity for of channel-reaches exceeding in some cases $4 \mathrm{~m} \mathrm{~s}^{-1}$ (Tab. 4). In case of the Moravskoslezké Beskydy Mts., it may be caused by relatively little coarse bed material in small headwater streams, unlike Alpine streams, for which the Eq. (11) was made and where it was tested.

The calculation of critical stream power per unit was succesfully used by Mao et al. (2008) in steppool streams. Firstly, we computed the magnitude of unit stream power in relation to the known value of culminative discharge in the Malá Ráztoka gauging station (almost $4 \mathrm{~m}^{3} \mathrm{~s}^{-1}$ ) and its derivation for other reaches (Tab. 5). A smaller value of stream power per unit in the MR1 reach is probably caused by the width of active channel. Derived discharges for the reaches of the Lubina basin may be less exact because of different geological conditions and moderate slopes in this basin. Still, we consider them to be usable. Due to lack of data we are not able to propose a relationship between transported particles and stream power per unit of acceptable reliability. The relationship we derived for three largest particles $\left(0.2 \mathrm{~m}<D_{i}<0.4 \mathrm{~m}\right)$ found on surfaces of the accumulations takes form

$\omega_{c i}=3.0397 D_{i}^{0.7885}\left(\mathrm{R}^{2}=0.0527\right)$

with $D_{i}$ in mm (Fig. 5). Generally, there is practically no relation between stream power per unit and maximal size of transported and deposited boulders.
This result allows us to state that critical stream power is dependent on local conditions such as particle-size distribution and packing and armouring of bed sediment together with the parameters used in Eq. (5) (discharge, bed gradient and channel width). Sediment supply patterns and intensity are other influencing factors of sediment load during floods.

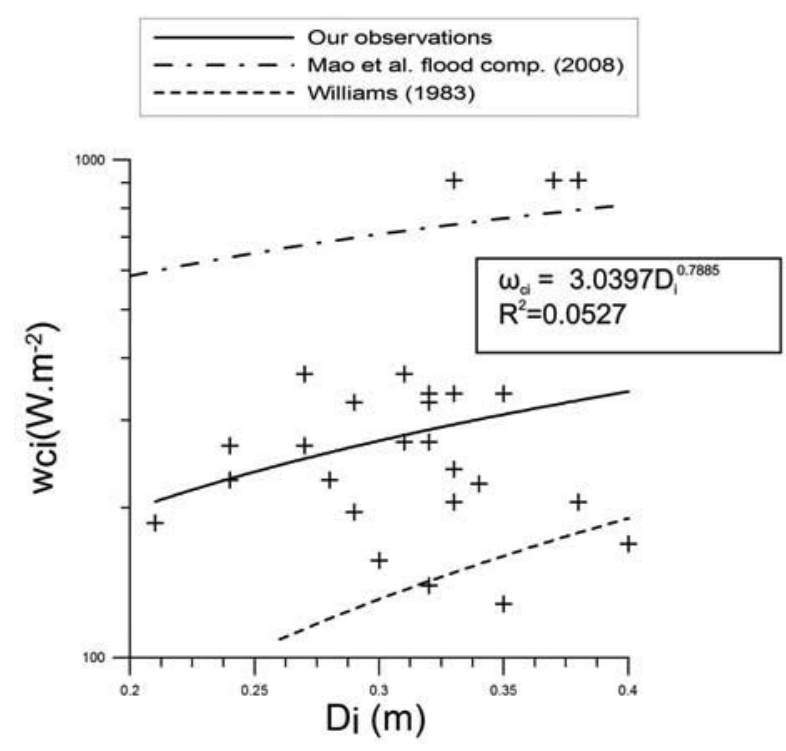

Fig. 5. Relationship between unit stream power and diameters of three largest particles $\left(0.2 \mathrm{~m}<D_{i}<0.4 \mathrm{~m}\right)$ of each accumulation.

$\mathrm{T}$ a b 1 e 4. Critical flow velocities acting on bed particles by Eq. (10) $\left(D_{i}=0.01,0.05,0.1,0.2,0.3,0.4\right.$ and 0.5$)$ and the calculation of flow velocity during the May 2010 flood by Eq. (11).

\begin{tabular}{lcccccccc}
\hline \multicolumn{9}{c}{ Critical velocity $v_{c i}\left[\mathrm{~m} \mathrm{~s}^{-1}\right]$} \\
Reach & $D_{i}=0.01 \mathrm{~m}$ & $D_{i}=0.05 \mathrm{~m}$ & $D_{i}=0.1 \mathrm{~m}$ & $D_{i}=0.2 \mathrm{~m}$ & $D_{i}=0.3 \mathrm{~m}$ & $D_{i}=0.4 \mathrm{~m}$ & $D_{i}=0.5 \mathrm{~m}$ & $\begin{array}{c}\text { Flow velocity } \\
\text { estimation } \\
v\left[\mathrm{~m} \mathrm{~s}^{-1}\right]\end{array}$ \\
\hline L1 & 0.97 & 1.20 & 1.32 & 1.44 & 1.52 & 1.58 & 1.63 & 3.28 \\
L2 & 0.97 & 1.20 & 1.32 & 1.44 & 1.52 & 1.58 & 1.63 & 2.35 \\
L3 & 0.92 & 1.14 & 1.31 & 1.36 & 1.44 & 1.52 & 1.54 & 2.87 \\
L4 & 0.92 & 1.14 & 1.31 & 1.36 & 1.44 & 1.52 & 1.54 & 4.23 \\
L5 & 1.01 & 1.25 & 1.37 & 1.50 & 1.58 & 1.64 & 1.69 & 3.72 \\
L6 & 1.02 & 1.26 & 1.38 & 1.51 & 1.60 & 1.66 & 1.71 & 3.95 \\
L7 & 0.97 & 1.21 & 1.36 & 1.49 & 1.58 & 1.64 & 1.69 & 1.98 \\
MR1 & 1.03 & 1.27 & 1.40 & 1.53 & 1.61 & 1.68 & 1.72 & 3.47 \\
MR2 & 0.98 & 1.21 & 1.33 & 1.45 & 1.53 & 1.59 & 1.64 & 2.86 \\
\hline
\end{tabular}

Using back calculations of Eq. (6), Eq. (7) and Eq. (8) we obtained values of the largest potential transported particles by the flood event. Tab. 4 also shows values computed by Eq. (6), (7) and Eq. (8) with respect to the largest particles found in the accumulations. Comparing the values calculated by Eq. (7) and Eq. (8) with the sizes of boulders deposited in Lubina and Malá Ráztoka accumulations 
we can observe underestimation trend of $\omega_{\text {ci }}$ values or derivated discharge values. Even in case of Eq. (6), the $\omega_{c i}$ values of which were the lowest in gravel-bed rivers, underestimation trend of values was observed in three cases (LU1, LU5 and LU7 reaches).

Another solved parameter, critical unit per discharge $\left(q_{c i}\right)$, shows us significant differences between the values observed in Alpine and Andean environments (Mao et al., 2008) and a midmountain type of relief such as the Moravskoslezské Beskydy Mts. Back calculations of $q_{c i}$ using Eq. (9) in most channel-reaches (except MR2 reach) underestimate c. 5 times the maximal diameter of potentially transported particles. The values ranged from $0.07-$ $-0.10 \mathrm{~m}$ of $b$-axis of three largest particles from each reach. Due to a higher $Q / w$ ratio in the MR2 reach, the values of $b$-axis of potentially transported stones are much higher and they reached more realistic values of $0.58 \mathrm{~m}$ (Fig. 6). Putting all data together, derived relationship takes the form

$q_{c i}=0.0115 D_{i}^{0.5479}\left(\mathrm{R}^{2}=0.0245\right)$

but again it is not statistically significant. In the same way, no significant trend of such a relationship is observed in a dataset excluding MR2 reach. However, a higher $Q / w$ ratio could be evidence of intensified fluvial processes forming the stream channel in MR2 reach. Derived Eq. (12) and Eq. (13) most likely show that bedload transport in steep slopes of small headwater streams may be less size-selective than in downstream reaches during large floods (Tab. 6).

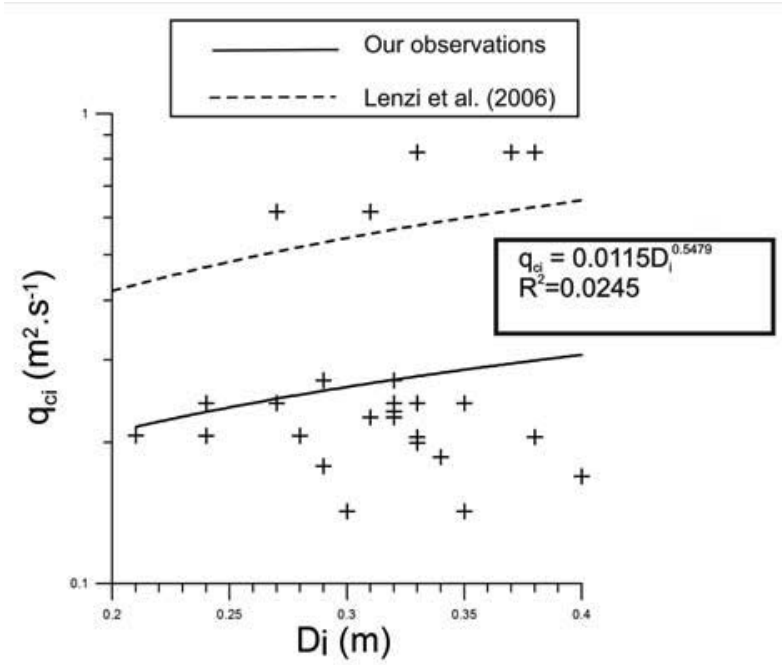

Fig. 6. Relationship between unit critical discharge and diameters of three largest particles $\left(0.2 \mathrm{~m}<D_{i}<0.4 \mathrm{~m}\right)$ of each accumulation.

\subsection{Reconstruction of total hydraulic roughness during the flood event}

Finally, we attempted to reconstruct the value of total hydraulic roughness during the May 2010 flood in studied reaches using Manning equation (Eq. (11)). Bankfull stage the gauging station of the Malá Ráztoka basin is observed at a discharge of c. $1 \mathrm{~m}^{3} \mathrm{~s}^{-1}$ (Fig. 4). Therefore, during the flood culmination on 18 May, these conditions were exceeded 4 times. Our presumptions are based on the fact that hydraulic roughness decreases in small streams

$\mathrm{T}$ a b 1 e 5. Culminative stream power per unit area during the 5/2010 flood and potential values of critical stream flow acting on the largest boulder deposited in an accumulation and obtained by Eq. (6), Eq. (7) and Eq. (8).

\begin{tabular}{lcccccccc}
\hline Reach & $\begin{array}{c}\omega_{f} \\
{\left[\mathrm{w} \mathrm{m}^{-2}\right]}\end{array}$ & $\begin{array}{c}D_{\text {imax }} \\
{[\mathrm{mm}]}\end{array}$ & $\begin{array}{c}D_{\text {i } \omega \text { (Mao et al. total }} \\
\text { competence) } \\
{[\mathrm{mm}]}\end{array}$ & $\begin{array}{c}D_{\text {i } \omega \text { (Mao et al. }} \\
\text { flood competence) } \\
{[\mathrm{mm}]}\end{array}$ & $\begin{array}{c}D_{\text {i } \omega \text { (Williams) }} \\
{[\mathrm{mm}]}\end{array}$ & $\begin{array}{c}\omega_{f} \max D_{i} \\
(\text { Mao et al. tot.c.) } \\
{\left[\mathrm{w} \mathrm{m}^{-2}\right]}\end{array}$ & $\begin{array}{c}\omega_{f} \max D_{i} \\
(\text { Mao et al. flood.c.) } \\
{\left[\mathrm{w} \mathrm{m}^{-2}\right]}\end{array}$ & $\begin{array}{c}\omega_{f} \max D_{i} \\
\text { (Williams) } \\
{\left[\mathrm{w} \mathrm{m} \mathrm{m}^{-2}\right]}\end{array}$ \\
\hline LU1 & 128 & 350 & 18 & 8 & 295 & 549 & 763 & 160 \\
LU2 & 157 & 300 & 27 & 13 & 344 & 510 & 709 & 131 \\
LU3 & 240 & 330 & 64 & 31 & 477 & 534 & 742 & 148 \\
LU4 & 196 & 290 & 42 & 20 & 409 & 501 & 698 & 126 \\
LU5 & 169 & 400 & 31 & 15 & 365 & 586 & 813 & 191 \\
LU6 & 224 & 340 & 55 & 26 & 452 & 542 & 753 & 154 \\
LU7 & 140 & 320 & 21 & 10 & 315 & 526 & 731 & 143 \\
MR1 & 339 & 350 & 130 & 64 & 623 & 549 & 763 & 160 \\
MR2 & 911 & 380 & 986 & 508 & 1332 & 572 & 794 & 178 \\
\hline
\end{tabular}

$\omega_{f}$ is stream power unit per area during the flood, $D_{i \max }-\mathrm{b}$-axis of the largest boulder deposited in an accumulation, $\mathrm{D}_{\mathrm{i} \omega}-\mathrm{b}$-axis of the largest potentially transported particles calculated using Eq. (6), (7) and (8) and $\omega_{f}$ max $D_{i}-$ value of stream power per unit, which would be able to transport the largest particle deposited in an accumulation as calculated by Eq. (6), (7) and (8). 
$\mathrm{T}$ a b 1 e 6. Comparison of values of observed critical discharge per unit and values of critical discharges per unit acting on the largest particle deposited in an accumulation (calculated by Eq. (9)).

\begin{tabular}{lcccc}
\hline Reach & $D_{\text {imax }}[\mathrm{m}]$ & $q_{\text {ci obs. }}\left[\mathrm{m}^{2} \mathrm{~s}^{-1}\right]$ & $q_{\text {ci }}($ Lenzi et al. $)\left[\mathrm{m}^{2} \mathrm{~s}^{-1}\right]$ & $D_{\text {iqci }}($ Lenzi et al. $)[\mathrm{m}]$ \\
\hline LU1 & 0.35 & 0.14 & 0.60 & 0.04 \\
LU2 & 0.30 & 0.14 & 0.63 & 0.04 \\
LU3 & 0.33 & 0.20 & 0.60 & 0.06 \\
LU4 & 0.29 & 0.18 & 0.54 & 0.05 \\
LU5 & 0.40 & 0.17 & 0.58 & 0.05 \\
LU6 & 0.34 & 0.19 & 0.53 & 0.06 \\
LU7 & 0.32 & 0.23 & 0.65 & 0.08 \\
MR1 & 0.35 & 0.24 & 0.59 & 0.09 \\
MR2 & 0.38 & 0.83 & 0.57 & 0.58 \\
\hline
\end{tabular}

$D_{\text {imax }}$ is b-axis of the largest boulder deposited in an accumulation, $q_{c i \text { obs }}$ - the value of maximal discharge per unit observed during the May 2010 flood, $q_{c i}$ - a value computed by Eq. (9) for $D_{i \max }, D_{i q c i}$ - a potential largest particle transported by $q_{c i}$ (obtained by Eq. (9)) during the May 2010 flood.

with increasing discharge until the streams overflow their banks. Likewise, form resistance usually prevails over particles resistance at high discharges. We introduced geometrical parameters of each reach measured during flood culmination (i.e. hydraulic radius and gradient) and critical stream velocity obtained by Eq. (10), based on critical shear stress putting the largest particles to motion, in order to extract $n$ hydraulic roughness parameter of Eq. (11).

The calculated values of $n$ parameter are much higher than the $n$ values known from lower gradient rivers (Chow, 1959) and they well correspond to a ratio of typical bed particle size parameter and geometric parameters of the local channel crosssections. The $n$ values obtained for cascade and step-pool reaches in both studied streams vary between 0.088 and 0.116 . In case of plain bed reach LU7 with predicted lower form resistance, the value of $n$ parameter decreased to 0.064 during this $Q_{100}$ flood event. For bankfull stage $\left(Q_{1}-Q_{2}\right)$, we introduced the value $D_{i}=0.05 \mathrm{~m}$ as a typical diameter of a potentially transported cobble during this stage and consequently we calculated critical velocities using Eq. (10). By introducing geometrical parameters of bankfull channel cross-section we obtained the values of $n$ parameter in a range of $0.10-0.14$ for cascade and step-pool reaches and 0.076 for a plain bed channel respectively.

\section{Conclusions}

This study deals strictly with accumulations developed as a result of fluvial bedload transport although colluvial processes such as small debris- flows can also participate in the sediment deposition in Beskydian headwater streams. The results show that low intensity/high magnitude floods $\left(\sim Q_{100}\right)$ in steep headwater streams can transport large amounts of coarse bed material and consequently deposit it in limited space between slopes and active channel if local critical conditions for movement change significantly. The $Q_{100}$ flood is capable of transporting almost all bed material up to $D_{95}-D_{99}$ of bed particles excluding the largest boulders and colluvial blocks. Dependences between transported $D_{i}$ and critical shear stress, $D_{\mathrm{i}}$ and critical velocity or $D_{i}$ and critical unit stream power demonstrated no close correlations. Williams (1983) supposed a range of nearly 40 times of unit stream power values necessary for the onset of grain motion of a given particle diameter in gravelbed streams during the same flow. According to $\mathrm{Yu}$ et al. (2009) bedload transport rate in Chinese mountain streams is very unstable and it differs as many as 1000 times under nearly identical flow conditions because of differences in available sediment load supplied from adjacent slopes within a year. That points to the importance of recognizing local settings of a stream bed and connections between the channel and sources of sediment inputs and consequently calibrating an explicit transport model to these local conditions. What still remains uncertain is the definition of exact critical conditions for sediment transport in high gradient streams. It is important to point out that forces necessary for the initiation of grain motion must be greater than those keeping particle in motion ( Hjulstrom, 1939), i.e. the instant value of shear stress, velocity, stream power or discharge is lower when a 
specific grain enters the transport stage or settles in an accumulation than the critical value initiating the motion. However, there is not much difference between critical values of both the grain incipient motion and settling in case of bedload type of transport and a relatively large size of particles.

Fluvial bedload transport in small mountain headwater basins is less size-selective than in lower gradient streams as shown by the absence of a transparent relationship between maximal $b$-axis length of a stone and critical unit discharge or critical unit stream power. There is not much difference in obtained values of critical velocity and critical shear stress necessary to initiate the motion of grain $\left(0.2<D_{i}<0.4 \mathrm{~m}\right)$ that is later deposited in an accumulation, which supports the theory of less sizeselective or even non-selective transport in steep torrents during large floods. In order to confirm or refuse this theory it is necessary to continue in the research in small basins $\left(\mathrm{A} \leq 1 \mathrm{~km}^{2}\right)$ at various flow conditions in different environments.

Acknowledgements. The research was supported by the Student Competition Grant No. SGS5/PřF/2010. We would like to thank the Forestry and Game Management Research Institute, Frýdek-Místek branch, for providing discharge data from the Malá Ráztoka instrumental basin. The authors also express sincere thanks to Monika Hradecká for English language revision.

\section{REFERENCES}

ABERLE J. and SMART G., 2003: The influence of roughness structure on flow resistance on steep slopes. J. Hydraul. Res., 41, 259-269.

BAGNOLD R. A., 1980: An empirical correlation of bedload transport rates in flumes and natural rivers. Proc. R. Soc. London, Ser. A, 372, 453-473.

BARRY J. J., BUFFINGTON J. M., KING J. G., 2004: A general power equation for predicting bedload transport rates in gravel bed rivers. Wat. Resour. Res., 40, W104001.

BARRY J. J., BUFFINGTON J. M., GOODWIN P., KING J. G., EMMETT W. W., 2008: Performance of bedload transport equations relative to geomorphic significance: Predicting effective discharge and its transport rate. J. Hydraul. Engng, 134, 5, 601-615.

BENDA L., HASSAN A., CHURCH M., MAY C. L., 2005: Geomorphology of steepland headwaters: The transition from hillslopes and channels. J. American Wat. Resour. Association, 41, 835-851.

BUFFINGTON J. M., MONTGOMERY D. R., 1997: A systematic analysis of eight decades of incipient motion studies, with special reference to gravel-bedded rivers. Wat. Resour. Res., 33, 1993-2029.

CHLEBEK A., JAŘABÁČ M., 1995: Posouzení závislosti prírůstku lesních porostů $v$ Beskydech na klimatu metodou faktorové analýzy. (In Czech.) Lesnictví, Vol. 41, 9, 426-431 .
CHOW V. T., 1959: Open-channel hydraulics. McGraw-Hill, New York, $680 \mathrm{p}$.

CHURCH M., ZIMMERMAN A., 2007: Form and stability of step-pool channels: Research progress. Wat. Resour. Res., Vol. 43, W03415, 21 pp.

COSTA J. E., 1983: Paleohydraulic reconstruction of flashflood peaks from boulder deposits in the Colorado Front Range. Geolog. Soc. Amer. Bull., 94, 986-1004.

DEMIR T., WALSH R. P. D., 2005: Shape and size characteristics of bedload transported during winter storm events in the Cwm Treweryn stream, brecon Bacon, South Wales. Turkish J. Earth Sci., Vol. 14, 105-121.

GOB F., PETIT F., BRAVARD J.-P., OZER A., GOB A., 2003: Lichenometric application to historical and subrecent dynamics sediment transport of a Corsican stream (Figarella River - France). Quarternary Sci. Rev., 22, 2111-2124.

HALWAS K. N., CHURCH M., 2002: Channel units in small, high gradient streams on Vancouver Island, British Columbia. Geomorphology, 43, 243-256.

HJULSTROM F., 1939: Transportation in detritus by mowing water. In: Trask P.D. (ed.): Recent Marine Sediments, a symposium. American Association of petroleum Geologist, Tulsa, Oklahoma, pp. 5-31.

LAMB M., DIETRICH W., VENDITTI J., 2008: Is the critical shear stress of incident sediment motion dependent on channel-bed slope? J. Geophys. Res. - Earth Surface 113. F02008, doi:10.1029/2007JF000831.

LENZI M. A., MAO L., COMITI F., 2006: When does bedload transport begin in steep boulder-bed stream? Hydrologic. Process., 20, 3517-3533.

MAO L., UYTTENDAELE G.P., IROUMÉ A., LENZI M.A., 2008: Field based analysis of sediment entrainment in two high gradient streams located in Alpine and Andine environments. Geomorphology, 93, 368-383.

MOLNAR P., DENSMORE A. L., MCARDELL B. W., TUROWSKI J., BURLANDO P., 2010: Analysis of change in the step-pool morphology and channel profile of a steep mountain stream following a large flood. Geomorphology, in press, doi:10.1016/j.geomorph.2010.08.014.

MONTGOMERY, D. R., BUFFINGTON J. M., 1997: Channel reach morphology in mountain drainage basins. Geologic. Soc. Amer. Bull., 109, 596-611.

NICKOLOTSKY A., PAVLOWSKY R. T., 2007: Morphology of step-pool in wilderness headwater stream: The importance of standatrizing geomorphic measurement. Geomorphology, 83, 294-306.

PÁNEK T., TÁBOŘÍK P., HRADECKÝ J., 2007: Gravitační rozpad hřbetu Čertova Mlýna (Moravskoslezské Beskydy). (In Czech.) Geologické výzkumy na Moravě a ve Slezsku $\mathrm{v}$ roce 2006, Brno, 124-129.

PARKER G., 1990: Surface-based bedload transport relation for gravel rivers. J. Hydraulic. Res., 28, 417-436.

PETIT F, GOB F., HOUBRECHTS G., ASSANI A. A., 2005: Critical stream power in gravel-bed rivers. Geomorphology, 69, 92-101.

POVODÍ ODRY, s.p., 2010: Press conference about flood 05-06 2010, 8. 6. 2010, Ostrava. (In Czech.) Online: < http://www.pod.cz/files/pro_media/2010/06/Povoden_2010 _Povodi_Odry.ppt>

RICKENMANN D., 1997: Sediment transport in Swiss torrents. Earth Surface Processes and Landforms, 22, 937-951.

RICKENMANN, D., CHIARI M., FRIEDL K., 2006: SETRAC - A sediment routing model for steep torrent channels. In R. Ferreira, E. A. J. Leal, and A. Cardoso 
(Eds.): River Flow 2006, Vol. 1, London, 843-852. Taylor \& Francis.

SHIELDS, A., 1936: Anwendung der Aehnlichkeitsmechanik der Turbulenzforschung auf die Geschiebebewegung. Mitt. Preuss. Versuchsanst. Wasserbau Schiffbau, 26, 5-24. English translation by W.P. Ott and J.C. van Uchelen, 43 pp., United States Dept. Agriculture Soil Conservation Service Cooperative Laboratory.

STRAHLER A. N., 1957: Quantitative analysis of watersheed geomoprhology. Transaction of the American Geophysical Union, 38, 913-920.

THOMPSON C. J., CROKE J., OGDEN R., WALLBRINK P., 2006: A morpho-statistical classification of mountain stream reachtypes in southeastern Australia. Geomorphology, 81, 43-65.

VIANELLO A., D’AGOSTINO V., 2007: Bankfull width and morphological units in an Alpine stream of the Dolomites (Northern Italy). Geomorphology, 83, 266-281.

WILLIAMS G. P., 1983: Paleohydrological methods and some examples from Swedish fluvial environments. Geografiska Annaler, 65A, 227-243.
WOHL E. E., MERRITT D. M., 2008: Reach-scale channel geometry of mountain streams. Geomorphology, 93, 168-185 .

WOLMAN M. G., 1954: A method of sampling coarse riverbed material. Transactions American Geophysical Union, Vol. 6, 35, 951-956.

YU G., WANG Z., ZHANG K, CHANG T., LIU H., 2009: Effect of incoming sediment on the transport rate of bed load in mountain streams. Int. J. Sediment Res., 24, 260-273 .

ZIMMERMANN A., CHURCH M., 2001: Channel morphology, gradient profiles and bed stresses during flood in a steppool channel of mountain streams. Geomorphology, 40, 311-327.

Received 10 March 2011

Accepted 19 October 2011 